\title{
Teaching NeuroImages: Acute necrotizing encephalopathy of childhood
}

\author{
Neuroimaging findings
}

Asthik Biswas, DNB, Mugil Varman, MD, Aditya Gunturi, MBBS, Sangeetha Yoganathan, DM, and Sridhar Gibikote, MD

Neurology ${ }^{\oplus}$ 2018;90:e177-178. doi:10.1212/WNL.0000000000004800
Correspondence

Dr. Biswas

asthikbiswas@gmail.com

Figure $1 \mathrm{MRI}$ shows symmetric thalamic swelling, brainstem and white matter involvement, and trilaminar appearance on apparent diffusion coefficient (ADC)
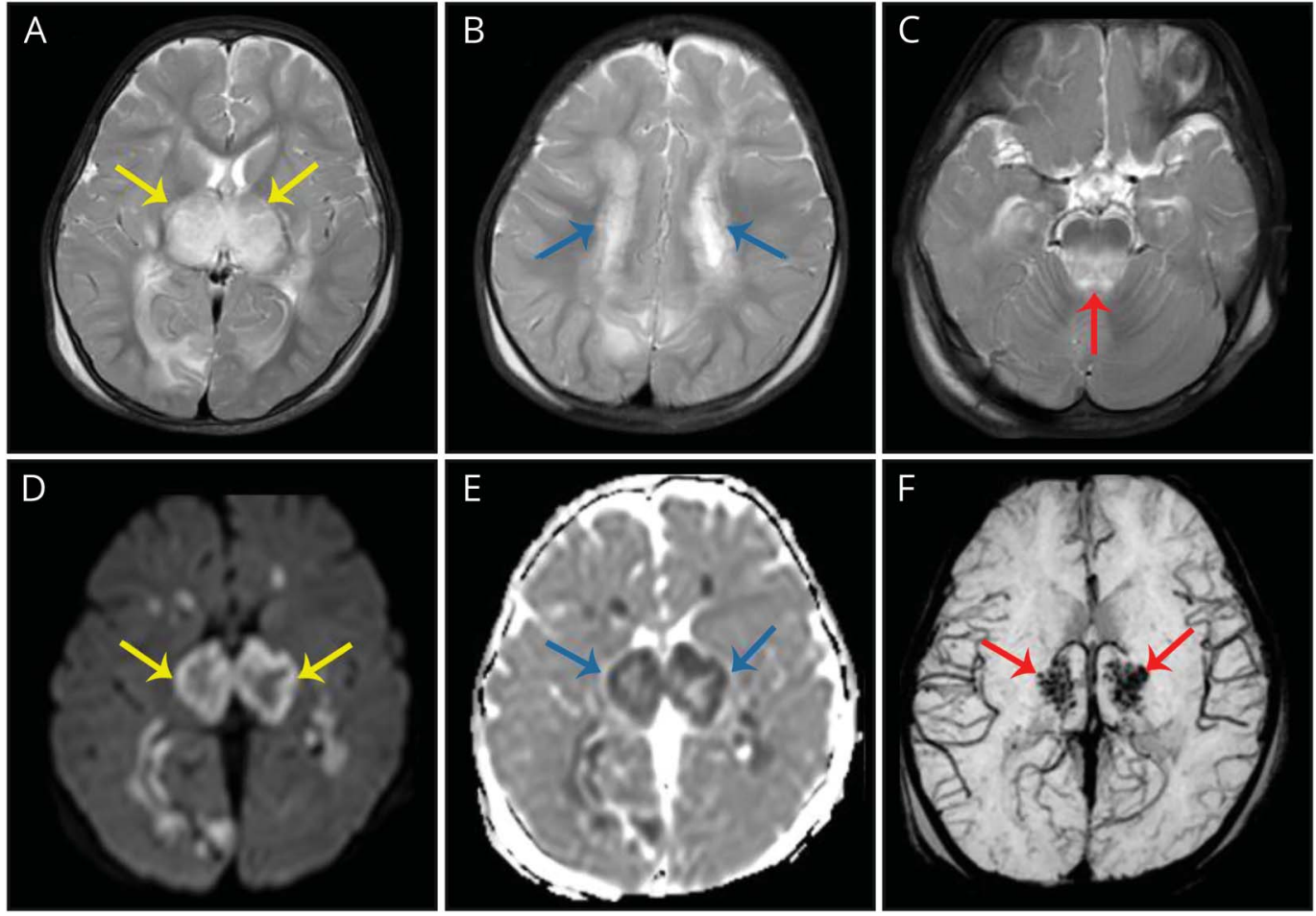

Axial T2-weighted images (A-C) show swelling and hyperintensity involving the thalami (A), cerebral white matter (B), and dorsal brainstem (C). The thalamic lesions show a trilaminar appearance on the diffusion-weighted imaging and ADC images (D, E). Punctate hemorrhagic foci are noted on the susceptibilityweighted imaging images $(F)$.

A 10-month-old infant was brought to the hospital in status epilepticus, preceded by a 2-day history of fever and loose stools. Brain MRI revealed swelling and T2 hyperintensity involving the thalami, white matter, and dorsal brainstem (figure 1). The thalamic lesions showed a trilaminar appearance on the diffusion-weighted imaging (DWI) and apparent diffusion coefficient (ADC) images, with hemorrhagic foci on susceptibility-weighted imaging (figures 1 and 2).

Acute necrotizing encephalopathy of childhood is a fulminant encephalopathy affecting infants and children. ${ }^{1}$ Viral infections (influenza, rotavirus, human herpesvirus-6), immune-mediated, and genetic (RANBP2 mutation) etiologies have been implicated as causative factors. ${ }^{2,3}$ The trilaminar appearance on DWI and ADC images and symmetric thalamic involvement is

MORE ONLINE

$\rightarrow$ Teaching slides:

links.lww.com/WNL/A84 characteristic.

From the Departments of Radiology (A.B., M.V., A.G., S.G.) and Neurosciences (S.Y.), Christian Medical College, Tamil Nadu, India.

Go to Neurology.org/N for full disclosures. Funding information and disclosures deemed relevant by the authors, if any, are provided at the end of the article. 
Figure 2 Axial apparent diffusion coefficient (ADC) image shows the characteristic trilaminar appearance

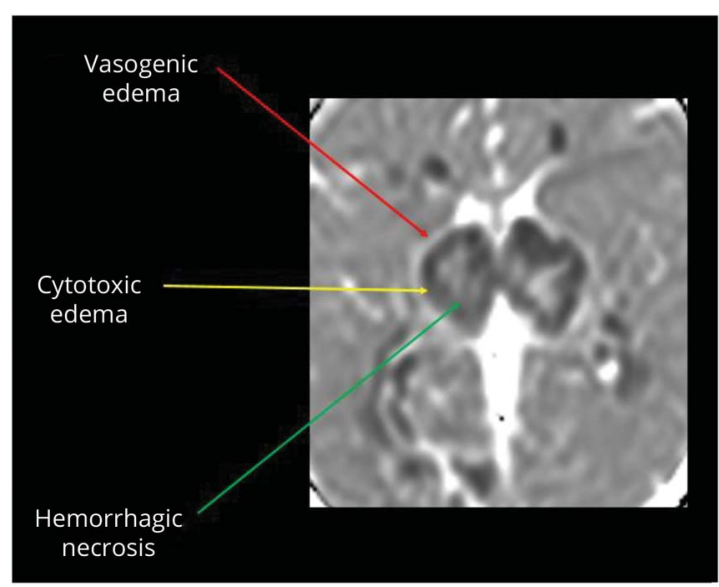

Axial ADC image shows the trilaminar appearance in better detail. The inner region of facilitated diffusion is due to hemorrhagic necrosis, middle layer of restricted diffusion is due to cytotoxic edema, and outer layer of facilitated diffusion is due to vasogenic edema.

\section{Author contributions}

Asthik Biswas: concept, image interpretation, and writeup of manuscript. Mugil Varman: image interpretation and preparation. Aditya Gunturi: image interpretation and preparation. Sangeetha Yoganathan: clinical input, critical revision for intellectual content. Sridhar Gibikote: critical revision for intellectual content.

\section{Study funding}

No targeted funding reported.

\section{Disclosure}

The authors report no disclosures relevant to the manuscript. Go to Neurology.org/N for full disclosures.

\section{References}

1. Mizuguchi M, Abe J, Mikkaichi K, et al. Acute necrotising encephalopathy of childhood: a new syndrome presenting with multifocal, symmetric brain lesions. J Neurol Neurosurg Psychiatry 1995;58:555-561.

2. Mizuguchi M. Acute necrotizing encephalopathy of childhood: a novel form of acute encephalopathy prevalent in Japan and Taiwan. Brain Dev 1997;19:81-92.

3. Neilson DE, Adams MD, Orr CMD, et al. Infection-triggered familial or recurrent cases of acute necrotizing encephalopathy caused by mutations in a component of the nuclear pore, RANBP2. Am J Hum Genet 2009;84:44-51. 


\section{Neurology}

\section{Teaching NeuroImages: Acute necrotizing encephalopathy of childhood: Neuroimaging findings}

Asthik Biswas, Mugil Varman, Aditya Gunturi, et al. Neurology 2018;90; $177-\mathrm{e} 178$

DOI 10.1212/WNL.0000000000004800

\section{This information is current as of January 8, 2018}

\section{Updated Information \&} Services

References

Subspecialty Collections

Permissions \& Licensing

Reprints including high resolution figures, can be found at: http://n.neurology.org/content/90/2/e177.full

This article cites 3 articles, 1 of which you can access for free at: http://n.neurology.org/content/90/2/e177.full\#ref-list-1

This article, along with others on similar topics, appears in the following collection(s):

All Pediatric

http://n.neurology.org/cgi/collection/all_pediatric

DWI

http://n.neurology.org/cgi/collection/dwi

MRI

http://n.neurology.org/cgi/collection/mri

Status epilepticus

http://n.neurology.org/cgi/collection/status_epilepticus

Information about reproducing this article in parts (figures,tables) or in its entirety can be found online at:

http://www.neurology.org/about/about_the_journal\#permissions

Information about ordering reprints can be found online:

http://n.neurology.org/subscribers/advertise

Neurology ${ }^{\circledR}$ is the official journal of the American Academy of Neurology. Published continuously since 1951 , it is now a weekly with 48 issues per year. Copyright Copyright @ 2018 American Academy of Neurology. All rights reserved. Print ISSN: 0028-3878. Online ISSN: 1526-632X.

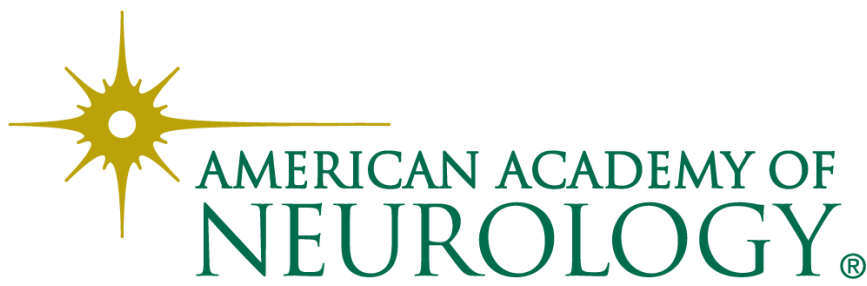

